\title{
Diagnostic role of IncRNA GAS5 and its genetic polymorphisms rs2067079, rs6790 and rs17359906 in rheumatoid arthritis
}

\author{
AZZA M. ELAMIR $^{1}$, SOHA SENARA ${ }^{2}$, NOHA KHALIFA ABDELGHAFFAR $^{3}$, \\ SYLVANA N. GABER ${ }^{4}$ and HASSAN SALEM EL SAYED ${ }^{1}$ \\ ${ }^{1}$ Medical Biochemistry Department; Departments of ${ }^{2}$ Rheumatology and Rehabilitation, ${ }^{3}$ Clinical Pathology and
${ }^{4}$ Medical Microbiology and Immunology, Faculty of Medicine, Fayoum University, Fayoum 63616, Egypt
}

Received May 7, 2021; Accepted July 7, 2021

DOI: $10.3892 /$ br.2021.1469

\begin{abstract}
The aim of the present study was to detect the serum levels of long non-coding RNA (lncRNA) growth arrest-specific 5 (GAS5) in patients with rheumatoid arthritis (RA) and healthy controls, and determine the association between the rs2067079, rs6790, and rs17359906 single-nucleotide polymorphisms (SNPs) of lncRNA GAS5 gene with RA risk in the Egyptian population. Reverse transcription-quantitative PCR and real-time PCR were used to measure the serum levels of lncRNA GAS5 and genotype the two distinct alleles at the SNP sites of lncRNA GAS5 gene in 200 patients with RA and 150 controls. The mean serum levels of lncRNA GAS5 were significantly lower in the patients with RA compared with the controls $(\mathrm{P}<0.0001)$, and the serum levels of lncRNA GAS5 were significantly negatively associated with erythrocyte sedimentation rate, $\mathrm{C}$-reactive protein levels and anti-cyclic citrullinated peptide levels in the patients with RA. The TT genotype of rs2067079 SNP was significantly associated with a decreased risk of RA [TT vs. $\mathrm{CC}$ : Odds ratio $(\mathrm{OR})=2.358 ; 95 \%$ confidence interval $(\mathrm{CI})$, 1.114-5.131; $\mathrm{P}=0.045)$ and the risk of $\mathrm{rs} 2067079$ SNP reduced with a recessive pattern ( $\mathrm{TT}$ vs. $\mathrm{TC}+\mathrm{CC}$ : $\mathrm{OR}=2.374 ; 95 \% \mathrm{CI}$, 1.091-5.123; $\mathrm{P}=0.037)$. rs6790 SNP was associated with RA risk in the recessive model (AA vs. GA + GG: $\mathrm{OR}=2.55$; 95\% $\mathrm{CI}=1.39-5.32 ; \mathrm{P}=0.02)$. No significant associations were noted between the rs17359906 SNP and RA risk $(\mathrm{P}>0.05)$ or between the lncRNA GAS5 levels and their respective genotypes at the three SNPs in patients with RA (all P>0.05). Based on the results of the present study, IncRNA GAS5 may serve as a biomarker for the early detection of RA. The TT genotype of rs2067079 SNP was significantly associated with a decreased risk of RA, and a reduced risk of rs2067079 SNP was observed
\end{abstract}

Correspondence to: Dr Azza M. Elamir, Medical Biochemistry Department, Faculty of Medicine, Fayoum University, Building 1, Elgamaa Street, Fayoum 63616, Egypt

E-mail: ama27@fayoum.edu.eg

Key words: long non-coding RNA growth arrest-specific 5, rheumatoid arthritis, single nucleotide polymorphism with a recessive pattern. rs6790 SNP was associated with RA risk in the recessive model.

\section{Introduction}

Rheumatoid arthritis (RA) is a common systemic autoimmune disorder that influences $\sim 1 \%$ of the general population. Advanced RA can be critically morbid with a decisively fatal rate that reduces survival by 10 years (1). RA is an irreversible inflammatory disorder that is identified based on increased inflammation, chronic synovitis, advanced joint devastation and general extra-articular manifestations, such as pericarditis, neuropathy, rheumatoid nodules and vasculitis. Despite several years of research, the pathophysiology of RA remains obscure to a great extent, although it has been determined that a range of inflammatory cytokines, such as tumor necrosis factor- $\alpha$ (TNF- $\alpha$ ) and interleukin-6 (IL-6) participate in RA pathogenesis $(2,3)$. Several biological processes, such as the growth and function of immune cells are regulated by long noncoding RNAs (lncRNAs). More recently, several lncRNAs have bene identified to be involved in the pathophysiology of autoimmune inflammatory disorders (4), such as RA (5), autoimmune thyroid disease and systemic lupus erythematosus (SLE) (6).

Growth arrest-specific 5 (GAS5), a type of lncRNA, is a 650-nt broad-spectrum growth repressor. 1ncRNA GAS5 is associated with an increased risk of SLE in mice (7). Furthermore, genetic analysis has revealed that 1q25, the chromosomal site of GAS5, is associated with the pathogenesis of SLE in humans (8).

LncRNA GAS5 is associated with RA, and it functions as an effective inhibitor of the glucocorticoid receptor (GR) through its RNA glucocorticoid response element (9). Several studies have detected IncRNA GAS5 in patients with autoimmune diseases and reported that GAS5 levels decrease markedly in these patients when compared with healthy individuals (10). Recently, genetic studies have reported several single-nucleotide polymorphisms (SNPs) that are associated with susceptibility to RA (11). Certain SNPs are present within exons; however, several other SNPs are present within introns, involving lncRNAs (12). Subsequently, lncRNA genetic polymorphisms may be associated with the molecular pathophysiology of RA, and investigating these variants may be 
valuable to reveal genetic aspects linked with the development of RA.

The aim of the present study was to detect the serum levels of lncRNA GAS5 in patients with RA and healthy controls and establish the association between rs2067079, rs6790 and rs17359906 SNPs of the lncRNA GAS5 gene with RA risk in the Egyptian population.

\section{Patients and methods}

Patients. In the present study, 350 Egyptian participants were recruited between January 2019 and June 2019 from the Rheumatology and Rehabilitation Department, Fayoum University Hospital, Fayoum University, Egypt. The participants were divided into two groups: 200 patients with RA (152 females and 48 males; mean age, $42.45 \pm 0.89$ years) and 150 age- and sex-matched healthy controls (112 females and 38 males; mean age, $40.85 \pm 0.99$ years).

The patients were diagnosed via clinical examination, radiological outcomes and laboratory screenings, and in accordance with the 2010 Rheumatoid Arthritis Classification Criteria (13). Exclusion criteria included other autoimmune diseases and other rheumatic, inflammatory or cardiovascular diseases. Written informed consent was obtained from all participants, and this study was approved by the Ethics Committee of the Faculty of Medicine, Fayoum University. The study procedures were performed in accordance with the ethical code of the World Medical Association Declaration of Helsinki for human experiments (14).

Sample collection. Fresh venous blood $(5 \mathrm{ml})$ from the antecubital vein of all participants was collected by venipuncture into EDTA-coated plain tubes to evaluate the erythrocyte sedimentation rate (ESR) using the Wintrobe method (15) and to extract the DNA for reverse transcription-quantitative (RT-q)PCR. In addition, 3-ml venous blood was collected and incubated at $37^{\circ} \mathrm{C}$ for $15 \mathrm{~min}$ and centrifuged at $3,000 \mathrm{x} \mathrm{g}$ for $10 \mathrm{~min}$ at room temperature to separate the serum, which was then stored in aliquots at $-80^{\circ} \mathrm{C}$.

Biochemical investigations. Serum was used to determine the levels of C-reactive protein (CRP), anti-cyclic citrullinated peptide (anti-CCP) antibodies and lncRNA GAS5 levels. CRP and anti-CCP levels were determined using a commercially available Human C-Reactive Protein ELISA kit (cat. no. RAB0096; Sigma-Aldrich; Merck KGaA) and an anti-CCP ELISA kit (Orgentec Diagnostika GmbH).

DNA extraction. Genomic DNA was segregated from whole peripheral blood using a QIAamp DNA blood mini-kit extraction kit (Qiagen $\mathrm{GmbH}$ ) according to the manufacturer's protocol. Purified samples of DNA were stored at $4{ }^{\circ} \mathrm{C}$ until required for PCR (16).

Real-time PCR. This phase included DNA amplification and identification of rs2067079 (C>T), rs6790 $(\mathrm{G}>\mathrm{A})$ and $\mathrm{rs} 17359906(\mathrm{G}>\mathrm{A})$ SNPs (Table I), (selected from the lncRNASNP2 database (bioinfo.life.hust.edu. $\mathrm{cn} /$ lncRNASNP\#!/) and situated in the chromosome locus transcribed into lncRNA GAS5 utilizing Real MOD ${ }^{\mathrm{TM}}$
RT-PCR MasterMix (cat. no. 44248; iNtRON Biotechnology). The quantity of DNA template used for SNP genotyping was $20 \mathrm{ng} / \mu \mathrm{l}$ in the reaction mix. DNA concentration was detected by estimating the absorption at $260 \mathrm{~nm}$ on a Nanodrop ND-1000 spectrophotometer. The sites of genetic information for the studied SNPs are substantiated by the National Center for Biotechnology Information database (ncbi.nlm.nih.gov).

RNA extraction and RT-qPCR. Total RNA (including small RNAs) were extracted from serum using an miRNeasy mini kit (Invitrogen; Thermo Fisher Scientific, Inc.), and RNA concentration was estimated on a NanoDrop ${ }^{\mathrm{TM}} 2000$ spectrophotometer (Thermo Fisher Scientific, Inc.). Total RNA was reverse-transcribed into cDNA using a miScript II RT kit (Qiagen $\mathrm{GmbH}$ ). Serum expression levels of lncRNA GAS5 were assessed using GAPDH as the internal control. The sequences of the primers were: GAS5 forward, 5'-AGGTRG GAGYGGGAGCATTCGG-3' and reverse, 5'-CCTGAACTG GAGCCACCAGCAGG-3'; and GAPDH forward, 5'-TAATRG GAGCCCGAGCGGGATA-3' and reverse 5'-TTTGCCCTG GAGGGACCAGCAAA-3'. All primers were part of the $\mathrm{RT}^{2}$ qPCR Primer assay kit (Qiagen GmbH). A Maxima SYBR Green PCR kit (Thermo Fisher Scientific, Inc.) was used for amplification according to the manufacturer's protocol, using $0.4 \mu \mathrm{l}$ of each primer (forward and reverse). The thermocycling conditions were follows: $95^{\circ} \mathrm{C}$ for $1 \mathrm{~min}$; followed by 42 cycles at $95^{\circ} \mathrm{C}$ for $10 \mathrm{sec}, 60^{\circ} \mathrm{C}$ for $30 \mathrm{sec}$ and $72^{\circ} \mathrm{C}$ for $1 \mathrm{~min}$. The $2^{-\Delta \Delta \mathrm{Cq}}$ method was used normalized to the internal control to calculate the relative expression levels of lncRNA GAS5 (17).

Statistical analysis. Data were analyzed using SPSS version 25 (IBM, Corp.). Plain descriptive analysis as numbers and percentages was performed for qualitative data, using standard deviations as a measurement of variation of quantitative parametric data and an inferential statistical tests. A Student's t-test was used to compare the differences between two groups. Pearson's correlation analysis was used to assess the correlation between quantitative variables; the value of the Pearson correlation coefficient (r) describes the strength and direction of a correlation ranging from -1 to +1 . Receiver operating curve analysis were plotted to determine the optimal cutoff levels of serum lncRNA GAS5 to differentiate between cases and controls. The area under the curve (AUC) was calculated to evaluate the accuracy of the diagnostic tests. LncRNA GAS5 rs2067079, rs6790 and rs17359906 SNPs in the patient and control groups were in Hardy-Weinberg equilibrium. $\mathrm{P}<0.05$ was considered to indicate a statistically significant difference.

\section{Results}

The present study included 350 participants: 200 patients with RA and 150 healthy controls. The mean age did not differ significantly between the two groups $(\mathrm{P}=0.245)$. The number of females was significantly higher than that of males in each group; however, there was no significant difference between the two groups in terms of sex $(\mathrm{P}=0.774$; Table II $)$.

The mean levels of ESR, CRP and anti-CCP antibodies were significantly higher in the patients with RA (54.02 \pm 2.31 , $2.56 \pm 0.10$ and $62.40 \pm 26.51$, respectively) than the controls $(8.05 \pm 1.04,0.59 \pm 0.06$ and $7.11 \pm 4.40$, respectively) $(\mathrm{P}<0.0001)$. 
Table I. Characteristics of the studied SNPs.

\begin{tabular}{lcccc}
\hline SNP & Chromosome & Position & Regulatory feature & Localization \\
\hline rs2067079 & 1 & 173866073 & Promoter/Enhancer & Intron \\
rs6790 & 1 & 173865494 & Promoter/Enhancer & Exon \\
rs17359906 & 1 & 173867056 & Promoter/Enhancer & Intron \\
\hline
\end{tabular}

SNP, single nucleotide polymorphism.

Table II. Characteristics of the study groups.

\begin{tabular}{lccc}
\hline Characteristics & Controls, $n=150$ & Patients, n=200 & P-value \\
\hline Age $^{\mathrm{a}}$ & $40.85 \pm 0.99$ & $42.45 \pm 0.89$ & 0.245 \\
Sex, n (\%) & & & 0.774 \\
Female & $112(74.6 \%)$ & $152(76 \%)$ & $48(24 \%)$ \\
Male & $38(25.4 \%)$ & & \\
\hline
\end{tabular}

${ }^{\mathrm{a}}$ Mean \pm standard deviation.

Table III. Laboratory parameters and lncRNA GAS5 levels in the study groups.

\begin{tabular}{|c|c|c|c|}
\hline Factor & Controls, $n=150$ & Patients, $n=200$ & P-value \\
\hline Erythrocyte sedimentation rate, $\mathrm{mm} / \mathrm{h}$ & $8.05 \pm 1.04$ & $54.02 \pm 2.31$ & $<0.0001^{\mathrm{a}}$ \\
\hline C-reactive protein, $\mathrm{mg} / \mathrm{dl}$ & $0.59 \pm 0.06$ & $2.56 \pm 0.10$ & $<0.0001^{\mathrm{a}}$ \\
\hline Anti-cyclic citrullinated peptide antibodies, U/ml & $7.11 \pm 4.40$ & $62.40 \pm 26.51$ & $<0.0001^{\mathrm{a}}$ \\
\hline lncRNA GAS5 & $1.16 \pm 0.03$ & $0.60 \pm 0.031$ & $<0.0001^{\mathrm{a}}$ \\
\hline
\end{tabular}

${ }^{a} \mathrm{P}<0.0001 .1$ ncRNA GAS5, long non-coding RNA growth arrest specific 5.

Table IV. Multivariate regression analysis of laboratory parameters for prediction of rheumatoid arthritis.

\begin{tabular}{lll}
\hline Variable & Odd ratio (95\% confidence interval) & P-value \\
\hline Erythrocyte sedimentation rate, $\mathrm{mm} / \mathrm{h}$ & $2.89(1.09-7.64)$ & $0.03^{\mathrm{a}}$ \\
C-reactive protein, $\mathrm{mg} / \mathrm{dl}$ & $4.09(1.35-12.38)$ & $0.01^{\mathrm{a}}$ \\
Anti-cyclic citrullinated peptide antibodies, $\mathrm{U} / \mathrm{ml}$ & $1.41(0.65-2.91)$ & $0.04^{\mathrm{a}}$ \\
Long non-coding RNA growth arrest specific 5 & $0.49(0.18-1.37)$ & 0.17 \\
\hline
\end{tabular}

${ }^{\mathrm{a}} \mathrm{P}<0.05$.

The mean levels of lncRNA GAS5 were significantly lower in the patients with RA $(0.60 \pm 0.031)$ than in the controls $(1.16 \pm 0.03)(\mathrm{P}<0.0001 ;$ Table III).

The serum levels of lncRNA GAS5 were significantly negatively correlated with ESR $(r=-0.64, \mathrm{P}<0.001), \mathrm{CRP}(\mathrm{r}=-0.38$, $\mathrm{P}<0.001)$, and anti-CCP antibodies $(\mathrm{r}=-0.58, \mathrm{P}<0.001)$ in $\mathrm{RA}$ patients (Fig. 1).

ROC curve analysis revealed high diagnostic value for IncRNA GAS5 with respect to the diagnosis of RA, with $89 \%$ sensitivity, $70 \%$ specificity, 0.75 area under the curve and $76 \%$ accuracy (Fig. 2). Multivariate regression analysis was used on ESR, CRP, anti-CCP and lncRNA GAS5 levels to determine which parameters independently predicted RA. The results showed that ESR [odds ratio $(\mathrm{OR})=2.89, \mathrm{P}=0.03$ ], $\mathrm{CRP}(\mathrm{OR}=4.09, \mathrm{P}=0.01)$ and anti-CCP antibodies $(\mathrm{OR}=1.41$, $\mathrm{P}=0.04$ ) were independent predictors for RA (Table IV).

Table $\mathrm{V}$ shows the genotype and allele frequencies of rs2067079, rs6790 and rs17359906 SNPs of the lncRNA GAS5 gene in patients with RA and normal controls. The TT genotype of rs2067079 SNP was significantly related to a decreased susceptibility of RA [TT vs. C: OR=2.358; 95\% confidence interval (CI), 1.114-5.131; $\mathrm{P}=0.045]$. Moreover, there was a 

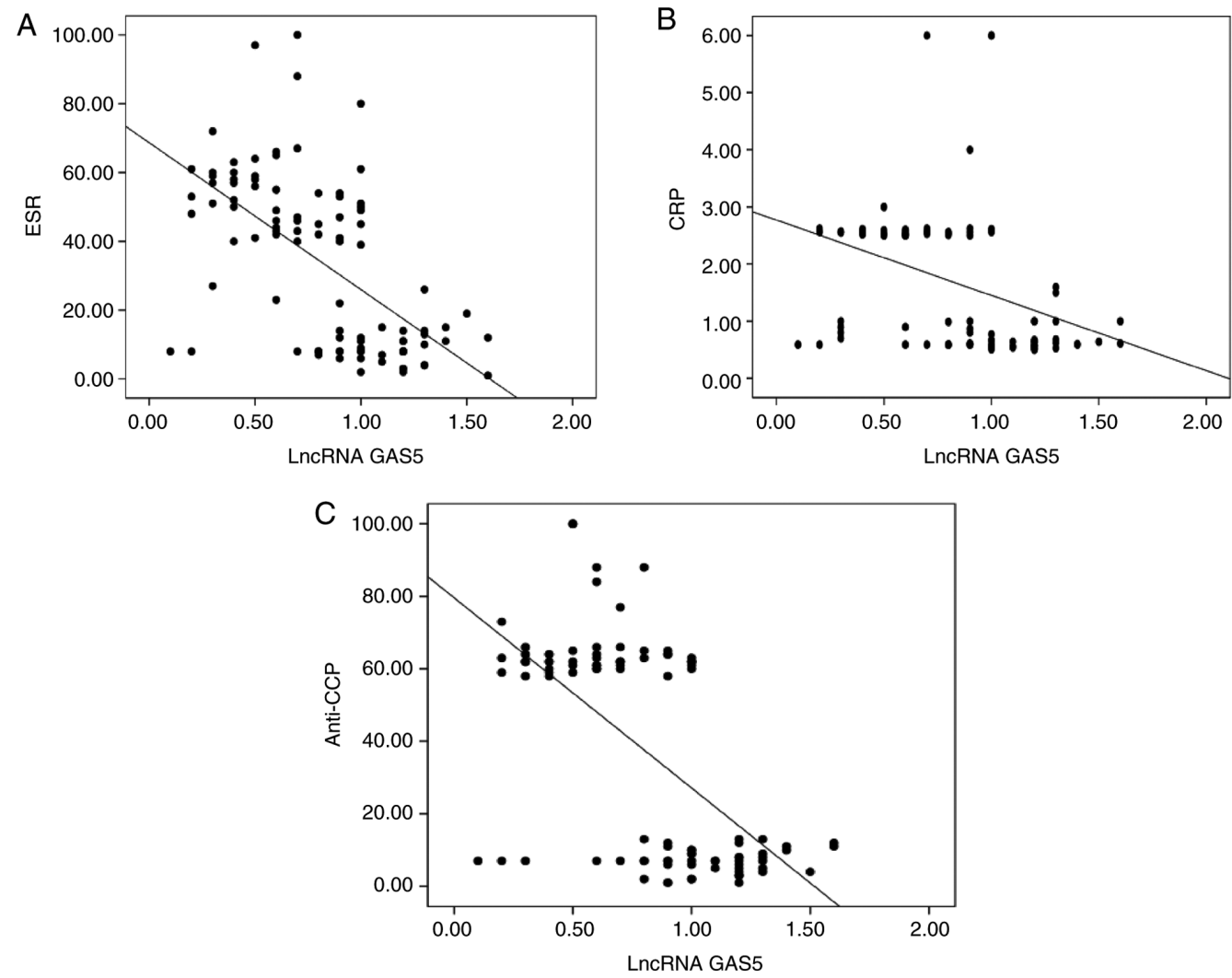

Figure 1. Correlations between lncRNA GAS5 and (A) ESR, (B) CRP and (C) anti-CCP in patients with RA. lncRNA GAS5, long non-coding RNA growth arrest-specific 5; ESR, erythrocyte sedimentation rate; CRP, C-reactive protein; anti-CCP, anti-cyclic citrullinated peptide; RA, rheumatoid arthritis.

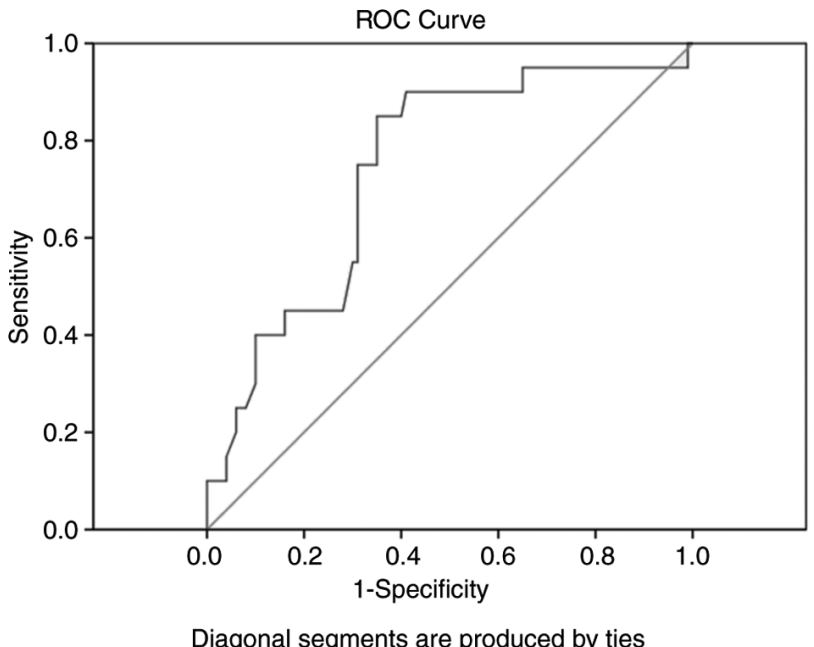

Figure 2. ROC curve analysis of long non-coding RNA growth arrest specific 5 as diagnostic marker of rheumatoid arthritis. ROC, receiver operating characteristic.

reduced risk of rs2067079 SNP with a recessive pattern (TT vs. $\mathrm{TC}+\mathrm{CC}: \mathrm{OR}=2.374 ; 95 \% \mathrm{CI}, 1.091-5.123 ; \mathrm{P}=0.037)$. The A allele of the rs6790 SNP was present at a higher frequency in the patients compared with the controls, but the difference was not statistically significant $(\mathrm{P}=0.06)$. The rs6790 SNP was associated with the risk of RA in the recessive model (AA vs. GA + GG: OR=2.55; 95\% CI, 1.39-5.32; $\mathrm{P}=0.02$ ). Regarding rs17359906 SNP, no significant difference was noted between patients and controls with regard to genotype or allele.
The association between lncRNA GAS5 levels and their corresponding genotype frequencies in the three SNPs were next analyzed. No significant differences were noted in the levels of lncRNA GAS5 amongst the different genotypes in patients with RA (Table VI).

\section{Discussion}

RA is an aggressive eradicative disorder characterized by joint destruction. The pathophysiology of RA is complicated and includes individual (genetic predispositions) and environmental (bacterial or viral infections) factors (18).

Recent studies have reported that IncRNAs are associated with numerous biological processes, particularly with immune cell function and the genetic pathogenesis of immune-related disorders $(4,19)$.

Furthermore, lncRNAs serve diverse crucial roles, which involve suppressing the transcriptional machinery, influencing mRNA stabilization, regulating DNA modulation, promoting RNA degradation and inducing immune cell apoptosis, in several physiological processes (20). A previous study has reported that the expression of $\sim 85$ lncRNAs in CD14 ${ }^{+}$ monocytes in patients with RA is significantly regulated by TNF- $\alpha$ and IL- 6 receptor inhibitors. These results suggest that IncRNAs are involved in RA pathophysiology (21).

LncRNA GAS5, located at chromosome 1q25, which was initially segregated from mice NIH 3 T3 cells, is a small nucleolar RNA host gene $(22,23)$. LncRNA GAS5 levels are decreased in $\mathrm{CD} 4^{+} \mathrm{T}$ and $\mathrm{B}$ cells in patients with RA and SLE compared with control healthy individuals (24). The expression of IncRNA 
Table V. Genotype and allele frequencies of SNPs of 1ncRNA GAS5 in the different study groups.

A, rs2067079 C>T

\begin{tabular}{|c|c|c|c|c|}
\hline Genotype & Controls, $\mathrm{n}=150(\%)$ & Patients, $\mathrm{n}=200,(\%)$ & P-value & OR $(95 \% \mathrm{CI})$ \\
\hline TT & $6(4)$ & $3(1.5)$ & $0.045^{\mathrm{a}}$ & $2.358(1.114-5.131)$ \\
\hline $\mathrm{CT}$ & $36(24)$ & $50(25)$ & 0.777 & $0.951(0.732-1.261)$ \\
\hline $\mathrm{CC}$ & $108(72)$ & $147(73.5)$ & Reference & \\
\hline $\mathrm{C}$ allele & $252(84)$ & $345(86.2)$ & 0.396 & $0.942(0.763-1.148)$ \\
\hline $\mathrm{T}$ allele & $48(16)$ & $55(13.8)$ & Reference & \\
\hline Dominant model & & & & $1.042(0.804-1.343)$ \\
\hline $\mathrm{CC}$ & $108(72)$ & $147(73.5)$ & 0.8 & \\
\hline $\mathrm{CT}+\mathrm{TT}$ & $42(28)$ & $53(26.5)$ & Reference & \\
\hline Recessive model & & & & $2.374(1.091-5.123)$ \\
\hline $\mathrm{TT}$ & $6(4)$ & $3(1.5)$ & $0.037^{\mathrm{a}}$ & \\
\hline $\mathrm{CT}+\mathrm{CC}$ & $144(96)$ & $197(98.5)$ & Reference & \\
\hline
\end{tabular}

B, rs6790 G>A

\begin{tabular}{|c|c|c|c|c|}
\hline Genotype & Controls, $\mathrm{n}=150(\%)$ & Patients, $\mathrm{n}=200,(\%)$ & P-value & OR $(95 \% \mathrm{CI})$ \\
\hline AA & $12(8)$ & $40(20)$ & 0.09 & $2.78(1.265 .88)$ \\
\hline GA & $66(44)$ & $80(40)$ & 0.56 & $1.06(0.64-1.78)$ \\
\hline GG & $72(48)$ & $80(40)$ & Reference & \\
\hline $\mathrm{G}$ allele & $210(70)$ & $240(60)$ & 0.06 & $1.49(1.04-2.12)$ \\
\hline A allele & $90(30)$ & $160(40)$ & Reference & \\
\hline Dominant model & & & & $1.33(0.82-2.15)$ \\
\hline GG & $72(48)$ & $80(40)$ & 0.49 & \\
\hline $\mathrm{GA}+\mathrm{AA}$ & $78(52)$ & $120(60)$ & Reference & \\
\hline Recessive model & & & & $2.55(1.39-5.32)$ \\
\hline AA & $12(8)$ & $40(20)$ & $0.02^{\mathrm{a}}$ & \\
\hline $\mathrm{GA}+\mathrm{GG}$ & $138(92)$ & $160(80)$ & Reference & \\
\hline
\end{tabular}

C, rs $17359906 \mathrm{G}>\mathrm{A}$

\begin{tabular}{|c|c|c|c|c|}
\hline Genotype & Controls, $\mathrm{n}=150(\%)$ & Patients, $\mathrm{n}=200,(\%)$ & P-value & OR $(95 \% \mathrm{CI})$ \\
\hline AA & $16(10.6)$ & $18(9)$ & 0.61 & $1.098(0.761-1.574)$ \\
\hline GA & $70(46.7)$ & $89(44.5)$ & 0.2 & $1.269(0.864-1.839)$ \\
\hline GG & $64(42.7)$ & $93(46.5)$ & Reference & \\
\hline $\mathrm{G}$ allele & $198(66)$ & $275(68.8)$ & 0.07 & $1.149(0.979-1.349)$ \\
\hline A allele & $102(34)$ & $125(31.2)$ & Reference & \\
\hline Dominant model & & & & $0.839(0.679-1.044)$ \\
\hline GG & $64(42.7)$ & $93(46.5)$ & 0.13 & \\
\hline $\mathrm{GA}+\mathrm{AA}$ & $86(57.3)$ & $107(53.5)$ & Reference & \\
\hline Recessive model & & & & $0.848(0.588-1.209)$ \\
\hline AA & $16(10.6)$ & $18(9)$ & 0.36 & \\
\hline $\mathrm{GA}+\mathrm{GG}$ & $134(89.4)$ & $182(91)$ & Reference & \\
\hline
\end{tabular}

${ }^{\mathrm{a}} \mathrm{P}<0.05$. OR, odds ratio; $\mathrm{CI}$, confidence interval.

GAS5 increases during growth arrest induced by serum starvation or suppression of mammalian target of rapamycin (24).

Furthermore, GAS5 can stimulate cell cycle arrest at the G0/G1 phase by suppressing the transcription of genes, such as glucocorticoid receptors and androgen, indicating that GAS5 participates in the pathophysiology of RA and SLE by inducing cell cycle arrest. GAS5 also serves as a microRNA (miR)sponge, such as for miR-21. As miR-21 is generally 
Table VI. Association of lncRNA GAS5 levels with their respective genotype in the patients with rheumatoid arthritis.

\begin{tabular}{lcrcc}
\hline Variable & Genotype & $\mathrm{n}$ & lncRNA GAS5 & P-value \\
\hline rs2067079 C>T & CC & 147 & 0.65 & 0.405 \\
& CT & 50 & 0.58 & \\
rs6790 G>A & TT & 3 & 0.90 & \\
& GG & 80 & 0.89 & 0.551 \\
rs17359906 G>A & GA & 80 & 0.56 & \\
& GA & 40 & 0.61 & \\
& GA & 93 & 0.68 & 0.519 \\
& AA & 89 & 0.81 & \\
& & 18 & 0.51 & \\
\hline
\end{tabular}

lncRNA GAS5, long non-coding RNA growth arrest specific 5.

implicated in enhancing Th17 cell differentiation $(25,26)$ and participates in the pathogenesis of several autoimmune disorders, the decreased expression of GAS5 may be involved in the pathophysiology RA and SLE via uncontrolled miR-21 function in Th17 cells (27). In the present study, the serum levels of lncRNA GAS5 were investigated in patients with RA and healthy controls. Considering the criteria for RA diagnosis, ESR, CRP levels, and anti-CCP antibody levels were assessed and the results showed that the mean values of these parameters significantly increased in the patients compared with the controls $(\mathrm{P}<0.0001)$. The mean levels of 1ncRNA GAS5 significantly decreased in the patients with RA compared with the controls $(\mathrm{P}<0.0001)$.

These findings are consistent with those of Mayama et al (10), who investigated the expression of 1ncRNA GAS5 in various autoimmune diseases. They revealed that GAS5 expression significantly decreased in the $\mathrm{CD}^{+} \mathrm{T}$ and $\mathrm{B}$ cells of patients with RA compared with healthy controls.

$\mathrm{Wu}$ et al (28) also reported that GAS5 expression significantly decreased in the plasma of patients with SLE compared with healthy controls. Furthermore, Li et al (29) examined three lncRNAs (Linc0597, lnc-DC and GAS5) in patients with SLE and found that the levels of these lncRNAs was significantly decreased in patients with SLE compared with healthy controls.

Several studies have proposed that numerous lncRNArelated SNPs are associated with the pathophysiology of autoimmune disorders. The GAS5 gene exists in the disease susceptibility region in the mice BXSB strain and causes glomerulonephritis with SLE. A locus on chromosome 9p21, including lncRNA ANRIL, is significantly associated with predisposition to type II diabetes. Furthermore, several related SNPs alter the transcription and processing of ANRIL transcripts in the pathogenesis of human diseases $(30,31)$.

In the present study, the association between rs2067079, rs6790 and rs17359906 SNPs of the lncRNA GAS5 gene with RA risk in the Egyptian population was assessed. The TT genotype of rs2067079 SNP was significantly associated with a decreased risk of RA. Moreover, there was a reduced risk of RA with the rs2067079 SNP with a recessive pattern.

Li et al (29) performed a study to elucidate the possible association between the rs2067079 C > T SNP of IncRNA
GAS5 and SLE risk, but found no significant association. Eftekharian et al (32) reported an association between rs2067079 SNP of lncRNA GAS5 and multiple sclerosis risk. They found a significantly higher percentage of the $\mathrm{T}$ allele of rs2067079 SNP in patients with MS than in healthy controls, and showed that this variant was associated with MS risk in a co-dominant and recessive patterns (32).

Several studies have revealed that certain SNPs in the promoter region of GAS5 can regulate its expression and are associated with the susceptibility to carcinomas. For example, rs6790 SNP is a biomarker for adverse effects resulting from chemoradiotherapy in patients with nasopharyngeal carcinoma (33). CHIP-seq data revealed that rs6790 SNP is located in an active promoter region or enhancer region, and silico analysis detected that this variant has a considerable feature of expression quantitative trait locus. Both CHIP-seq data and silico analysis revealed the involvement of rs6790 SNP in the variations of GAS5 expression. In addition, rs6790 was revealed to exert repressor effects of GAS5 on the transcriptional activity of glucocorticoid receptor in autoimmune disorders (32).

The A allele of rs6790 SNP existed at a higher frequency in the patients compared with the controls, but it was not statistically significant. rs6790 was associated with the risk of RA in the recessive model. Wu et al (34) reported that the genotype frequencies of the rs6790 SNP of 1ncRNA GAS5 gene was significantly associated with the risk of RA, but they did not reveal the relation of this SNP with RA risk with dominant and recessive patterns. Thus, further studies are required to explain the specific role of IncRNA GAS5 and its polymorphisms in RA development.

In conclusion serum lncRNA GAS5 levels were significantly decreased in patients with RA, which indicates that it is a candidate biomarker for the early diagnosis of RA, highlighting its potential for use in the early detection of RA for improved treatment outcomes. The TT genotype of rs2067079 SNP of lncRNA GAS5 was significantly associated with a decreased risk of RA. Furthermore, there was a reduced risk of rs2067079 SNP with a recessive pattern, whereas rs6790 SNP was associated with RA risk in the recessive model.

\section{Acknowledgements}

Not applicable.

\section{Funding}

This research did not receive any specific grant from funding agencies, it was entirely sponsored by Fayoum University under the supervision of its research committee.

\section{Availability of data and material}

The datasets used and/or analyzed during the present study are available from the corresponding author on reasonable request.

\section{Authors' contributions}

AME, HSES, NKA and SNG performed the experiments and participated in data analysis. SS recruited the participants and participated in data analysis. All authors participated 
in designing the study, performing statistical analyses and writing the manuscript. All authors have read and approved the final manuscript. AME, HSES, NKA, SNG and SS confirm the authenticity of all the raw data.

\section{Ethics approval and consent to participate}

Written informed consent was obtained from all participants, and this study was approved by the Ethics Committee of the Faculty of Medicine, Fayoum University. The study procedures were performed in accordance with the ethical code of the World Medical Association Declaration of Helsinki for human experiments.

\section{Patient consent for publication}

Not applicable.

\section{Competing interests}

The authors declare that they have no competing interests.

\section{References}

1. Lee DM and Weinblatt ME: Rheumatoid arthritis. Lancet 358 903-911, 2001.

2. Solus JF, Chung CP, Oeser A, Li C, Rho YH, Bradley KM, Kawai VK, Smith JR and Stein CM: Genetics of serum concentration of IL- 6 and TNF $\alpha$ in systemic lupus erythematosus and rheumatoid arthritis: A candidate gene analysis. Clin Rheumatol 34: 1375-1382, 2015.

3. Yamanaka H: TNF as a target of inflammation in rheumatoid arthritis. Endocr Metab Immune Disord Drug Targets 15: 129-134, 2015

4. Wu GC: Immunoregulation function of long noncoding RNA in rheumatic diseases. Chin J Dis Control Prev 20: 1165-1171, 2016.

5. Messemaker TC, Frank-Bertoncelj M, Marques RB, Adriaans A, Bakker AM, Daha N, Gay S, Huizinga TW, Toes REM, Mikkers HMM and Kurreeman F: A novel long non-coding RNA in the rheumatoid arthritis risk locus TRAF1-C5 influences C5 mRNA levels. Genes Immun 17: 85-92, 2016.

6. Zhang F, Wu L, Qian J, Qu B, Xia S, La T, Wu Y, Ma J, Zeng J, Guo Q, et al: Identification of the long noncoding RNA NEAT1 as a novel inflammatory regulator acting through MAPK pathway in human lupus. J Autoimmun 75: 96-104, 2016.

7. Haywood MEK, Rose SJ, Horswell S, Lees MJ, Fu G, Walport MJ and Morley BJ: Overlapping BXSB congenic intervals, in combination with microarray gene expression, reveal novel lupus candidate genes. Genes Immun 7: 250-263, 2006.

8. Wu Y, Zhang F, Ma J, Zhang X, Wu L, Qu B, Xia S, Chen S, Tang $\mathrm{Y}$ and Shen N: Association of large intergenic noncoding RNA expression with disease activity and organ damage in systemic lupus erythematosus. Arthritis Res Ther 17: 131, 2015.

9. Kino T, Hurt DE, Ichijo T, Nader N and Chrousos GP: Noncoding RNA gas5 is a growth arrest- and starvation-associated repressor of the glucocorticoid receptor. Sci Signal 3: ra8, 2010.

10. Mayama T, Marr AK and Kino T: Differential expression of glucocorticoid receptor Noncoding RNA repressor gas 5 in autoimmune and inflammatory diseases. Horm Metab Res 48: 550-557, 2016.

11. Okada Y, Wu D, Trynka G, Raj T, Terao C, Ikari K, Kochi Y, Ohmura K, Suzuki A, Yoshida S, et al: Genetics of rheumatoid arthritis contributes to biology and drug discovery. Nature 506 : 376-381, 2014

12. Kumar V, Wijmenga $\mathrm{C}$ and Withoff S: From genome-wide association studies to disease mechanisms: Celiac disease as a model for autoimmune diseases. Semin Immunopathol 34: 567-580, 2012.

13. Aletaha D, Neogi T, Silman AJ, Funovits J, Felson DT, Bingham III CO, Birnbaum NS, Burmester GR, Bykerk VP, Cohen MD, et al: 2010 Rheumatoid arthritis classification criteria: An American college of rheumatology/European league against rheumatism collaborative initiative. Ann Rheum Dis 69: $1580-1588,2010$
14. World Medical Association (WMA): WMA Declaration of Helsinki - Ethical Principles for Medical Research Involving Human Subjects. WMA, Helsinki, 1964. https://www.wma. net/policies-post/w ma-declaration-of-helsinki-ethical-principles-for-medical-research-involving-human-subjects/. Latest Updated July 9, 2018.

15. Sinton JR: Clinical value of some methods of estimating erythrocyte sedimentation rate. Br Med J 1: 391-393, 1948.

16. Salazar LA, Hirata MH, Cavalli SA, Machado MO and Hirata RD: Optimized procedure for DNA isolation from fresh and cryopreserved clotted human blood useful in clinical molecular testing. Clin Chem 44: 1748-1750, 1988.

17. Livak KJ and Schmittgen TD: Analysis of relative gene expression data using real-time quantitative PCR and the 2(-Delta Delta C(T)) method. Methods 25: 402-408, 2001.

18. McInnes IB and Schett G: The pathogenesis of rheumatoid arthritis. N Engl J Med 365: 2205-2219, 2011.

19. Wu GC, Pan HF, Leng RX, Wang DG, Li XP, Li XM and Ye DQ: Emerging role of long noncoding RNAs in autoimmune diseases. Autoimmun Rev 14: 798-805, 2015.

20. Iyer MK, Niknafs YS, Malik R, Singhal U, Sahu A, Hosono Y, Barrette TR, Prensner JR, Evans JR, Zhao S, et al: The landscape of long noncoding RNAs in the human transcriptome. Nat Genet 47: 199-208, 2015.

21. Müller N, Döring F, Klapper M, Neumann K, Schulte DM, Türk K, Schröder JO, Zeuner RA, Freitag-Wolf S, Schreiber S and Laudes M: Interleukin- 6 and tumour necrosis factor- $\alpha$ differentially regulate lincRNA transcripts in cells of the innate immune system in vivo in human subjects with rheumatoid arthritis. Cytokine 68: 65-68, 2014.

22. Zhang Z, Zhu Z, Watabe K, Zhang X, Bai C, Xu M, Wu F and Mo YY: Negative regulation of lncRNA GAS5 by miR-21. Cell Death Differ 20: 1558-1568, 2013.

23. Tu ZQ, Li RJ, Mei JZ and Li XH: Down-regulation of long non-coding RNA GAS5 is associated with the prognosis of hepatocellular carcinoma. Int J Clin Exp Pathol 7: 4303-4309, 2014.

24. Pickard MR and Williams GT: Molecular and cellular mechanisms of action of tumour suppressor GAS5 LncRNA. Genes (Basel) 6: 484-499, 2015.

25. Murugaiyan G, da Cunha AP, Ajay AK, Joller N, Garo LP, Kumaradevan S, Yosef N, Vaidya VS and Weiner HL: MicroRNA-21 promotes Th17 differentiation and mediates experimental autoimmune encephalomyelitis. J Clin Invest 125: 1069-1080, 2015.

26. Dong L, Wang X, Tan J, Li H, Qian W, Chen J, Chen Q, Wang J, Xu W, Tao C and Wang S: Decreased expression of microRNA-21 correlates with the imbalance of Th17 and Treg cells in patients with rheumatoid arthritis. J Cell Mol Med 18: 2213-2224, 2014.

27. Song J, Ahn C, Chun $\mathrm{CH}$ and Jin EJ: A long non-coding RNA, GAS5, plays a critical role in the regulation of miR-21 during osteoarthritis. J Orthop Res 32: 1628-1635, 2014.

28. Wu GC, Li J, Leng RX, Li XP, Li XM, Wang DG, Pan HF and Ye DQ: Identification of long non-coding RNAs GAS5, linc0597 and lnc-DC in plasma as novel biomarkers for systemic lupus erythematosus. Oncotarget 8: 23650-23663, 2017.

29. Li J, Wu GC, Zhang TP, Yang XK, Chen SS, Li LJ, Xu SZ, Lv TT, Leng RX, Pan HF and Ye DQ: Association of long noncoding RNAs expression levels and their gene polymorphisms with systemic lupus erythematosus. Sci Rep 7: 15119, 2017.

30. Wallace C, Smyth DJ, Maisuria-Armer M, Walker NM, Todd JA and Clayton DG: The imprinted DLK1-MEG3 gene region on chromosome $14 \mathrm{q} 32.2$ alters susceptibility to type 1 diabetes. Nat Genet 42: 68-71, 2010.

31. Pasmant E, Sabbagh A, Vidaud M and Bièche I: ANRIL, a long noncoding RNA, is an unexpected major hotspot in GWAS. FASEB J 25: 444-448, 2011.

32. Eftekharian MM, Noroozi R, Komaki A, Mazdeh M, Taheri M and Ghafouri-Fard S: GAS5 genomic variants and risk of multiple sclerosis. Neurosci Lett 701: 54-57, 2019.

33. Li Q, Ma G, Sun SH, Xu Y and Wang B: Polymorphism in the promoter region of lncRNA GAS5 is functionally associated with the risk of gastric cancer. Clin Res Hepatol Gastroenterol 42: 478-482, 2018

34. Wu J, Zhang TP, Zhao YL, Li BZ, Leng RX, Pan HF and Ye DQ: Decreased H19, GAS5, and linc0597 expression and association analysis of related gene polymorphisms in rheumatoid arthritis. Biomolecules 10: 55, 2019. 